\title{
HisTORIA, WSPÓŁCZESNOŚĆ I PRZYSZŁOŚĆ KATOLICKICH SZKÓŁ PRAWNICZYCH - PERSPEKTYWA AMERYKAŃSKA
}

\section{Wstęp}

Katolickie szkoły prawnicze ${ }^{1}$ są częścią amerykańskiego systemu edukacji prawniczej już od półtora wieku. Z upływem czasu coraz bardziej problematyczne stało się podanie ich differentia specifica wyróżniającej je spośród świeckich i innych religijnie afiliowanych szkół prawniczych. Zamierzeniem stojącym u podstaw artykułu jest wskazanie wyznaczników tożsamości katolickich szkół prawniczych, których posiadanie legitymowałoby dalsze owocne istnienie tych szkół pod auspicjami Kościoła katolickiego. W pierwszej kolejności przybliżono genezę katolickich szkół prawniczych w Stanach Zjednoczonych i ukazano ich postępującą sekularyzację na tle przemian społecznych i kulturowych. Następnie dokonano syntezy głównych przejawów i przyczyn współcześnie głębokiego kryzysu tożsamości nominalnie katolickich amerykańskich szkół prawniczych. W ostatniej części opracowania sięgając do konstytucji apostolskiej papieża Jana Pawła II Ex Corde Ecclesiae ${ }^{2}$ oraz postulatów części amerykańskiej

* Dr hab., prof. Uniwersytetu Rzeszowskiego; e-mail: grzegorzmaron@op.pl, ORCID ID: https:/ / orcid.org/0000-0002-3861-9103.

1 Termin "school of law" czy "law school” tłumaczony jest w artykule jako "szkoła prawnicza”, a nie dosłownie jako "szkoła prawa”. Drugi ze zwrotów, jakkolwiek również poprawny, wydaje się w większym stopniu rodzić skojarzenia z pewnym nurtem w jurysprudencji (np. szkoła prawa naturalnego, literacka szkoła prawa) niż z ośrodkiem edukacji prawniczej.

2 Konstytucja apostolska Ojca Świętego Jana Pawła II z dnia 15 sierpnia 1990 r. o uniwersytetach katolickich, Ex Corde Ecclesiae [online], https://opoka.org.pl/biblioteka/W/ WP/jan_pawel_ii/konstytucje/o_uniwersytetach_15081990.html [dostęp: 24.03.2020 r.], 
jurysprudencji nakreślono wizję katolickiej szkoły prawniczej integralnie łączącej profesjonalizm z wyraźną własną katolicką tożsamością. Uwagi $\mathrm{w}$ tej materii, jakkolwiek formułowane $\mathrm{w}$ odniesieniu do - i przez pryzmat - doświadczeń amerykańskich, są bardziej uniwersalnej natury, zachowując w ocenie autora aktualność także w stosunku do katolickich szkół prawniczych poza Stanami Zjednoczonymi.

\section{Geneza i ewolucja katolickich szkół prawniczych w Stanach Zjednoczonych}

Datacja początków amerykańskich szkół prawniczych rodzi pewne trudności ${ }^{3}$. Kwestią sporną jest ustalenie, która z nich powstała jako pierwsza. O miano to rywalizują nieistniejąca obecnie Litchfield Law School w stanie Connecticut oraz William \& Mary Law School w stanie Wirginia. Druga z wymienionych szkół powstała w 1779 r. Z kolei jako rok założenia Litchfield Law School podaje się albo 1773/74 - co czyniłoby ją najstarszą szkołą prawniczą - albo 1784 r., co oznaczałoby pierwszeństwo William \& Mary Law School ${ }^{4}$. Z kolei powstały w 1817 r. Harvard Law School rości sobie miano najstarszej szkoły prawniczej nieprzerwanie działającej w Stanach Zjednoczonych. W rzeczywistości szkoły prawnicze natenczas miały niewiele wspólnego ze współczesnym rozumieniem tego pojęcia. Ich istnienie sprowadzało się do zatrudnienia przez college profesora czy profesorów prawa, którzy kształcili przyszłych prawników. Pierwsze szkoły prawnicze nie były wyraźnie wyodrębnione instytucjonalnie w strukturze college'u bądź uniwersytetu. W działalności

\footnotetext{
dalej: ECE. Zob. także Konstytucja apostolska Papieża Franciszka z dnia 27 grudnia 2017 r. o uniwersytetach i wydziałach kościelnych, Veritatis Gaudium [online], http://www.vatican.va/content/francesco/pl/apost_constitutions/documents/papa-francesco_costituzione-ap_20171208_veritatis-gaudium.html [dostęp: 24.03.2020 r.].

3 O akademickim kształceniu prawników w Stanach Zjednoczonych zob. A. Rochowicz, Edukacja prawnicza w USA, Palestra 1994, nr 7/8, s. 181-186.

4 Zob. Debate Over the First Law School in America [online], https://scholarship.law. wm.edu/lawschooldebate1966/ [dostęp: 27.02.2020 r.].
} 
badawczej i dydaktycznej nie występował też rygorystyczny podział na poszczególne dyscypliny naukowe ${ }^{5}$.

Szkoły prawnicze przypominające te obecne zaczęły funkcjonować w Stanach Zjednoczonych dopiero w latach 70-80. XIX w. Do tego czasu model edukacji prawniczej opierał się na praktykach zawodowych czy stażu przyszłego adepta prawa u doświadczonego prawnika, przypominając relację patrona i aplikanta. Na wskazany okres przypadają też początki amerykańskich katolickich szkół prawniczych. Za najstarszą zwykle uznaje się Notre Dame Law School powstałą w 1869 r. i powiązaną ze Zgromadzeniem Świętego Krzyża. Nie jest to jednak do końca prawdą. W 1843 r. utworzono bowiem szkołę prawniczą na jezuickim Saint Louis University, ale już po czterech latach zaprzestała działalności, będąc ponownie otwartą dopiero w 1908 r. ${ }^{6}$ Do końca XIX w. powstały cztery kolejne katolickie szkoły prawnicze: Georgetown Law School (1870), Duquesne Law School (1878), DePaul Law School (1897) oraz Columbus Law School na Katolickim Uniwersytecie Ameryki (1897).

W latach 1900-1939 utworzono 14 katolickich szkół prawniczych ${ }^{78}$. Po II wojnie światowej dynamika powstawania nowych katolickich ośrodków edukacji prawniczej zaczęła słabnąć. Ostatnią utworzoną w 2001 r. katolicką szkołą prawniczą jest University of St. Thomas Law School. Ogólnie w Stanach Zjednoczonych funkcjonuje 29 szkół prawniczych

5 Zob. N. Oman, The Oldest Law School [online], https://concurringopinions.com/ archives/2006/08/the_oldest_law.html [dostęp: 27.02.2020 r.].

6 Zob. D. Owens, American Law Schools in Their Second Century, Journal of Legal Education 1976, t. 28, nr 2, s. 210.

7 W kolejności chronologicznej: Creighton University School of Law (1904), Fordham University School of Law (1905), Loyola University Chicago School of Law (1908), Marquette University School of Law (1908), Santa Clara University School of Law (1911), University of Detroit-Mercy School of Law (1912), Gonzaga University School of Law (1912), University of San Francisco School of Law (1912), Loyola University New Orleans School of Law (1914), Loyola Law School/Loyola Marymount University School of Law (1920), University of Dayton School of Law (funkcjonowała w latach 1922-35, ponownie uruchomiona w 1974 r.), St. John's University School of Law (1925), Boston College School of Law (1929), St. Mary's University School of Law (1934).

8 University of San Diego School of Law (1949), Seton Hall University School of Law (1951), Villanova University School of Law (1953), Pontifical Catholic University of Puerto Rico School of Law (1961), Seattle University School of Law (1972), Barry University School of Law (1993), St. Thomas University School of Law (Florida) (1984), Ave Maria School of Law (1999), University of St. Thomas School of Law (Minnesota) (2001). 
o afiliacji katolickiej, z czego 14 działa pod auspicjami Towarzystwa Jezusowego. Ich absolwenci stanowią $17 \%$ wszystkich absolwentów studiów prawniczych w tym kraju ${ }^{9}$.

U podstaw tworzenia katolickich szkół prawniczych stały w pierwszej kolejności czynniki i motywy społeczno-ekonomiczne, a nie te o charakterze naukowym, pedagogicznym, formacyjnym czy ewangelizacyjnym ${ }^{10}$. Edukacja prawnicza na katolickich uczelniach była adresowana do katolickich imigrantów, a w zasadzie ich potomków, którzy w uzyskaniu prawniczego wykształcenia upatrywali szansy na podniesienie swojego statusu materialnego i społecznego. Dwoma innymi głównymi celami kreowania katolickich szkół prawniczych było wzmocnienie prestiżu macierzystego katolickiego uniwersytetu oraz finansowe wsparcie go ${ }^{11}$.

Protestancka większość społeczeństwa amerykańskiego krytycznie, a niekiedy nawet wrogo, odnosiła się do katolików. W XIX i przez znaczną część XX w. utrzymywał się w Stanach Zjednoczonych silny antykatolicki natywizm, który osłabł dopiero w ostatnich dekadach. Katolików postrzegano jako "obcych" i powątpiewano w ich obywatelską lojalność. Panowało przekonanie, że katolicy są nie tyle Amerykanami wiernymi republikańskim wartościom zamieszkiwanego państwa, ale poddanymi papieża gotowymi bezkrytycznie podporządkować się jego woli i nauczaniu ${ }^{12}$.

Do połowy XX w. znaczna część studentów katolickich szkół prawniczych kształciła się w ramach studiów wieczorowych. Spowodowane to było faktem, że studenci jednocześnie pracowali zawodowo na pełnym etacie. $\mathrm{Z}$ tego też powodu katolickie szkoły prawnicze były w większości usytuowane nie w obrębie campusu, ale w śródmieściu w sąsiedztwie sądów, kancelarii prawniczych, banków i innych zakładów pracy zatrudniających studentów. Ułatwiało to studentom godzenie pracy zawodowej z prawniczą edukacją.

Katolickie szkoły prawnicze ukierunkowane na zaspokojenie aspiracji społecznego awansu kolejnych pokoleń katolickich imigrantów oraz

9 Zob. J.M. Breen, L.J. Strang, The Road Not Taken: Catholic Legal Education at the Middle of the Twentieth-Century, American Journal of Legal History 2011, t. 51, nr 4, s. 553.

10 Wyjątkiem od tej reguły była geneza utworzenia Columbus Law School na Katolickim Uniwersytecie Ameryki. W zamierzeniu niniejsza szkoła prawnicza miała służyć specyficznie katolickiej edukacji prawniczej.

11 Zob. J.M. Breen, L.J. Strang, The Road..., s. 558-584.

12 Zob. P. Jenkins, The New Anti-Catholicism: The Last Acceptable Prejudice, New York 2003. 
ambicji ich macierzystych uniwersytetów dążyły przede wszystkim do profesjonalizacji. W Stanach Zjednoczonych o perspektywach zawodowych prawnika decyduje status i pozycja szkoły prawniczej, którą ukończył. Pozyskanie prestiżu i renomy w środowisku prawniczym i akademickim przesłaniało katolickim szkołom prawniczym troskę i starania o własną wyraźną religijną tożsamość, która wyróżniałaby je spośród świeckich i innych religijnie afiliowanych szkół prawniczych. Niniejsza hierarchia priorytetów miała przełożenie na politykę kadrową oraz program nauczania katolickich szkół prawniczych. Wprawdzie zatrudnianymi profesorami byli zwykle katolicy, ale nie przykładano większej wagi odnośnie do ich zdolności i chęci do przekazywania studentom treści jurydycznych w świetle katolickiej tradycji filozoficzno-teologicznej.

Katolickiej tożsamości szkół prawniczych od samego początku ich istnienia nie sprzyjał też ugruntowany w Stanach Zjednoczonych w drugiej połowie XIX w. model edukacji prawniczej, a właściwie szerzej - ogląd prawa, propagowany przez Ch.C. Langdella. Był on nie tylko wieloletnim dziekanem Harvard Law School, ale też uchodzi za ojca amerykańskiego prawniczego pozytywizmu. Prawnicza działalność naukowo-dydaktyczna miała być według Ch.C. Langdella podporządkowana paradygmatowi scjentyzmu, w którym nie było miejsca na rozważanie kwestii aksjologicznych i metafizycznych. Pojęcie prawa miało wyczerpywać się w prawie pozytywnym.

Od lat 20. minionego stulecia za sprawą szkoły realizmu prawnego założenia prawniczego pozytywizmu zaczęto powszechnie kwestionować w Stanach Zjednoczonych. Nie oznaczało to jednak bardziej sprzyjających okoliczności dla szerszego inkorporowania do nauki i edukacji prawniczej elementów katolickiej tradycji intelektualnej ${ }^{13}$. Pozytywiści i realiści w jednym byli zgodni: prawo i jego nauczanie musi być wolne od transcendencji i innej niż konwencjonalnej (konsensualnej) moralności. Według O.W. Holmesa "prawników wierzących w prawo naturalne” charakteryzuje „naiwny stan umysłu"14.

Jak powyżej wskazano, profesjonalizacja katolickich szkół prawniczych miała pierwszeństwo przed sprofilowaniem programu nauczania w sposób responsywny wobec katolickiej spuścizny duchowo-intelektualnej.

13 O bogactwie katolickiej tradycji intelektualnej zob. A. MacIntyre, God, Philosophy, Universities: A Selective History of the Catholic Philosophical Tradition, Lanham 2009.

14 O.W. Holmes, Natural Law, Harvard Law Review 1918, t. 32, s. 41. 
Włączeniu do działalności dydaktycznej treści religijnych czy optyki religijnej nie ułatwiały animozje pomiędzy władzami szkoły prawniczej a władzami całego uniwersytetu katolickiego. Zarządcy katolickich szkół prawniczych (board of trustees) toczyli spory z kierownictwem uczelni dotyczące $\mathrm{z}$ reguły dwóch kwestii. Po pierwsze, sprzeciwiali się przekazywaniu wypracowanego przez siebie dochodu do budżetu uniwersytetu celem finansowego wsparcia dla mniej dochodowych wydziałów. Po drugie, katolickie szkoły prawnicze niedługo po swoim powstaniu zaczęły przejawiać tendencje emancypacyjne i separatystyczne.

Nieuprawnione i krzywdzące byłoby jednak twierdzenie, że katolickie szkoły prawnicze w Stanach Zjednoczonych od swego zarania całkowicie zdominowała postawa upodabniania się do świeckich szkół prawniczych. Aktywność badawczo-dydaktyczna uwzględniająca katolickie nauczanie oraz działalność misyjna i formacyjna tych szkól, jakkolwiek nie będąca główną racją ich powstania, była pomimo to do lat 50. zauważalna i niemarginalna, choć zarazem nie pierwszorzędna.

W okresie tym w programie nauczania (curriculum) większości katolickich szkół prawniczych figurował przedmiot Jurysprudencja - zwykle jako przedmiot obligatoryjny. Stanowił on odpowiednik, znanego na polskich wydziałach prawa, przedmiotu Teoria i filozofia prawa. Wykłady z Jurysprudencji były ukierunkowane wokół problematyki prawa naturalnego, rozumianego w duchu neoscholastycyzmu. Jusnaturalizm na katolickich uczelniach prawniczych znajdował się więc pod dominującym wpływem myśli św. Tomasza z Akwinu. Elementy nauczania katolickiego pojawiały się także w ramach przedmiotu Etyka. W niektórych szkołach prowadzono ponadto zajęcia przybliżające katolicką naukę społeczną oraz prawo kanoniczne.

Profesorowie katolickich szkół prawniczych podjęli też $\mathrm{w}$ latach 30-50. intelektualną polemikę $\mathrm{z}$ reprezentantami realizmu prawnego, sprzeciwiając się założeniu o rozdzieleniu prawa i moralności. W kontekście sporu z realistami katoliccy juryści opublikowali wiele wartościowych monografii i artykułów naukowych, w których bronili konieczności i potrzeby związków prawa pozytywnego z prawem naturalnym w ujęciu neotomistycznym ${ }^{15}$. Po doświadczeniach II wojny światowej jusnaturalistyczne spojrzenie na prawo zyskało większą przychylność w środowisku

15 Zob. J.M. Breen, L.J. Strang, The Forgotten Jurisprudential Debate: Catholic Legal Thought's Response to Legal Realism, Marquette Law Review 2015, t. 98, nr 3, s. 1203-1311; 
prawniczym - nie tylko tym europejskim (np. Gustaw Radbruch), ale także w Stanach Zjednoczonych. Na czas powojennego „odrodzenia” prawa naturalnego przypada powstanie w 1947 r. Instytutu Prawa Naturalnego na Notre Dame Law School. Od 1956 r. instytut ten zaczął wydawać periodyk Natural Law Forum propagujący myśl jusnaturalistyczną. Z kolei w 1955 r. ukazał się pierwszy numer czasopisma Catholic Lawyer (z czasem przemianowany na The Journal of Catholic Legal Studies) wydawany przez St. John's Univeristy Law School.

Katolickie szkoły prawnicze były też natenczas zasadniczo katolickie w sensie demograficznym i kulturowym. Większość kadry profesorskiej oraz zdecydowaną większość studentów stanowili katolicy. W gronie wykładowców znajdowały się wówczas osoby duchowne, aczkolwiek wśród prowadzących zajęcia dominowali katolicy reprezentujący laikat. Profesorowie jakkolwiek statystycznie nieczęsto w prowadzonych wykładach nawiązywali do katolickiej myśli filozoficzno-teologicznej czy katolickiej nauki społecznej, to zarazem rzadko publicznie kwestionowali oficjalną doktrynę katolicką. „Katolickość” omawianych szkół przejawiała się też w życiu duchowym wspólnoty akademickiej. Przy szkołach powstawały kaplice, w których sprawowana była codzienna eucharystia. Wykładowcy i studenci uczestniczyli dorocznie w tzw. "czerwonej mszy" ${ }^{\prime 16}$. Odbywały się wydarzenia religijno-towarzyskie, jak modlitewne śniadanie (prayer breakfast). W oficjalnym harmonogramie organizacji roku akademickiego przewidywano rekolekcje czy dni skupienia dla społeczności akademickiej. Czymś naturalnym wówczas była obecność symboliki religijnej w budynkach szkoły, zwłaszcza obecność krzyża na ścianach pomieszczeń.

Od lat 60-70. ubiegłego wieku gwałtownie nasilił się proces sekularyzacji katolickich szkół prawniczych. Katolicka tożsamość tych szkół pozostawiająca i dawniej sporo do życzenia - stawała się coraz bardziej fasadowa i iluzoryczna. Na niniejszym stanie rzeczy zaciążyło wiele czynników. W okresie tym nastąpiły głębokie zmiany społeczne o wymowie

ciż, The Golden Age that Never Was: Catholic Law Schools from 1930-1960 and the Question of Identity, Journal of Catholic Social Thought 2010, t. 7, nr 2, s. 489-522.

16 "Czerwona msza" (Red Mass) to msza święta w rycie rzymskim odprawiana na rozpoczęcie każdego nowego roku sądowego (legal year). Biorą w niej udział sędziowie, prokuratorzy, adwokaci, profesorowie i studenci prawa. Uczestnicy modlą się podczas niej o przewodnictwo i wsparcie Ducha Św. w wykonywaniu prawniczej profesji w duchu prawdy i sprawiedliwości. Termin nawiązuje do czerwonego koloru szat liturgicznych. 
kontrreligijnej, jak rewolucja seksualna, ruch hipisowski czy tzw. druga fala feminizmu. Prywatystyczne i antyinstytucjonalne rozumienie religii nie ominęło też wielu amerykańskich katolików. Po Soborze Watykańskim II zaczął postępować laksyzm w podejściu części wiernych i duchownych do oficjalnego nauczania katolickiego. Doszedł do tego kryzys powołań kapłańskich oraz liczne wystąpienia ze stanu kapłańskiego. Przykładowo w Towarzystwie Jezusowym w Stanach Zjednoczonych prowadzącym, jak powyżej zaznaczono, połowę katolickich szkół prawniczych - liczba członków spadła z poziomu 8400 w 1965 r. do poziomu 2395 członków w 2013 r. ${ }^{17}$

Intelektualiści głównego liberalnego nurtu niemal jako dogmat zaczęli traktować wyłączenie argumentów i wartości religijnych z szeroko rozumianego dyskursu publicznego. Krytyczny stosunek do obecności religijnej perspektywy w działalności badawczo-dydaktycznej uzasadniano tym, że religia, a przede wszystkim chrześcijaństwo, jest irracjonalna, antydeliberatywna, konfliktogenna i apodyktyczna. Dla liberalizmu politycznego religia stała się niemal synonimem tego, co antytetyczne wobec nauki ${ }^{18}$.

W 1967 r. w miejscowości Land O’Lakes 26 wpływowych przedstawicieli katolickiej społeczności akademickiej ze Stanów Zjednoczonych i Kanady podpisało oświadczenie, będące swoistą deklaracją niezależności katolickich uniwersytetów od władz kościelnych. W dokumencie opowiedziano się za "prawdziwą autonomią i wolnością akademicką w obliczu władzy jakiegokolwiek rodzaju, świeckiej czy duchownej, zewnętrznej wobec wspólnoty akademickiej"19.

$\mathrm{Na}$ drodze pielęgnowania własnej katolickiej tożsamości stanęły też wymogi akredytacyjne formułowane przez Amerykańskie Stowarzyszenie Szkół Prawniczych (Association of American Law Schools, AALS) oraz Stowarzyszenie Prawników Amerykańskich (American Bar Association, ABA) polegające m.in. na kulturowej, w tym religijnej, różnorodności studentów i wykładowców. Co prawda uzyskanie akredytacji

17 Zob. P. Shaugnessy, Are the Jesuits Catholic? [online], Weekly Standard z dnia 3 czerwca 2002 r., https:/ / www.weeklystandard.com/ paul-shaughnessy/are-the-jesuits-catholic [dostęp: 28.02.2020 r.].

18 Zob. G.M. Marsden, The Outrageous Idea of Christian Scholarship, New York 1998.

19 Land O'Lakes Statement. The Idea of the Catholic University [online], Wisconsin 1967: $\S 1$ Statement on the Nature of the Contemporary Catholic University, https://cushwa. nd.edu/assets/245340/landolakesstatement.pdf [dostęp: 28.02.2020 r.]. 
obu organizacji nie jest warunkiem umożliwiającym prowadzenie szkoły prawniczej, ale w praktyce jej nieposiadanie dyskwalifikuje taką szkołę w środowisku prawniczym i ogranicza możliwości zawodowe jej absolwentom. Brak akredytacji istotnie utrudnia rekrutację, co jest z kolei kluczowe z punktu widzenia ekonomicznego, skoro głównym źródłem dochodów szkoły jest czesne studentów.

Władze katolickich szkół prawniczych zaczęły w swoim religijnym profilu upatrywać przeszkody czy balastu w staraniach o środki publiczne dostępne dla instytucji edukacyjnych. Przekonanie, iż religijne elementy $\mathrm{w}$ tożsamości uczelni utrudniają pozyskiwanie funduszy publicznych nie było do końca bezpodstawne w świetle niejednolitego orzecznictwa amerykańskiego. Case law Sądu Najwyższego Stanów Zjednoczonych dostarcza zarówno rozstrzygnięć, w których różne formy finansowego wsparcia dla szkół czy uczelni religijnych z budżetu stanowego lub lokalnego uznawano za zgodne, jak i za sprzeczne z konstytucyjną zasadą rozdziału kościoła i państwa (Establishment Clause) ${ }^{20}$.

Wskazane powyżej okoliczności per se nie skazywały katolickich szkół prawniczych na utratę swej katolickiej tożsamości. Czynnikiem decydującym o tym, że szkoły te poszły w kierunku głębokiej sekularyzacji była ich polityka kadrowa ${ }^{21}$. Pomiędzy 1965 a 1975 r. liczba studentów prawa wzrosła dwukrotnie z ponad 55 do 111 tys. ${ }^{22} \mathrm{~W}$ nowych warunkach demograficznych także katolickie szkoły prawnicze musiały istotnie zwiększyć liczbę pracowników naukowo-dydaktycznych. W selekcji wykładowców nie kierowano się kryterium ich wyznania czy zgodności prezentowanych przez nich poglądów z nauczaniem katolickim ${ }^{23}$.

Paradoksalnie bycie absolwentem katolickiej uczelni stawało się przeszkodą do późniejszego zatrudnienia go w niej w charakterze

20 Zob. T. D'Agostino, Religious Charter Schools: Are They Constitutionally Permissible?, Journal of School Choice 2018, t. 12, nr 4, s. 506-527.

${ }^{21}$ Zob. J.M. Breen, L.J. Strang, A Brief History of American Catholic Legal Education: The Arc of an Uncertain Identity, w: American Law from a Catholic Perspective: Through a Clearer Lens, red. R.J. Rychlak, Lanham 2016, s. 31-33.

22 Zob. Law School Enrollment [online], serwis internetowy Law School Transparency Data Dashboard, https://data.lawschooltransparency.com/enrollment/all/ [dostęp: 28.02.2020 r.].

${ }^{23}$ Zob. J.M. Breen, L.J. Strang, The Thinness of Catholic Legal Education, a Review of Robert J. Kaczorowski, Fordham University Law School: A History, University of St. Thomas Law Journal 2019, t. 15, nr 2, s. 496. 
wykładowcy. Pod wpływem oczekiwań AALS i ABA katolickie szkoły prawnicze praktykę zasilania kadry własnymi absolwentami - wydawałoby się naturalną - traktowały za rodzaj niepożądanego "chowu wsobnego" (inbreeding). Miernikiem profesjonalizmu stało się posiadanie kadry zróżnicowanej demograficznie, w tym pod kątem wyznawanej religii. Masowe zatrudnianie niekatolików oraz minimalizowanie liczby wykładowców będących kapłanami (co częściowo wymuszał spadek powołań i przypadki wystąpień z zakonów) było formą leczenia własnych kompleksów i wyzwalania się z rzekomego „kulturalnego i intelektualnego katolickiego getta" ${ }^{24}$.

Z programów nauczania usuwano przedmioty i kursy, w ramach których dotychczas w ograniczonym stopniu odwoływano się do katolickiej tradycji intelektualnej. Osłabło też życie duchowe społeczności akademickiej oraz szacunek dla kulturowego wymiaru religii. Zaprzestawano praktyki dorocznych „czerwonych mszy” i rekolekcji. Jako „niewygodny” zaczęto nawet traktować symbol krzyża, np. w 1974 r. usunięto krzyże w budynkach Gonzaga University School of Law ${ }^{25}$.

Kryzys tożsamości, jaki dotknął katolickie szkoły prawnicze, postępował tak intensywnie, że w już w 1975 r. Th. Shaffer pesymistycznie odnotowywał, że szkoły te „rzadko wykraczają poza pustosłowie o prawie naturalnym, które dawno temu stało się bardziej hasłem niż ideą, obecnie nie będąc ani hasłem ani ideą"26.

W sytuacji wyjałowienia tożsamości czymś spodziewanym stał się sprzeciw znacznej części środowiska akademickiego nominalnie „katolickich” szkół prawniczych wobec aplikowania do tych szkół norm konstytucji apostolskiej papieża Jana Pawła II o uniwersytetach katolickich, Ex Corde Ecclesiae z dnia 15 sierpnia 1990 r. ${ }^{27}$ Wyartykułowane w konstytucji wymogi, jakim powinna odpowiadać katolicka uczelnia,

24 Tamże, s. 511.

25 Zob. L.J. Nelson III, God and Man in the Catholic Law School, The Catholic Lawyer 1981, t. 26, nr 2, s. 127.

26 Zob. Th. Shaffer, Christian Theories of Professional Responsibility, Southern California Law Review 1975, t. 48, s. 722.

${ }^{27}$ W 2000 r. wydano dokument będący rozszerzoną wersją Ex Corde Ecclesiae dostosowaną do specyfiki edukacji akademickiej i wspólnoty katolickiej w Stanach Zjednoczonych (The Application of "Ex Corde Ecclesiae" for the United States). Wszedł on w życie 3 maja $2001 \mathrm{r}$. 
zostały w większości zignorowane przez katolickie ośrodki edukacji prawniczej $^{28}$.

\section{Kryzys tożsamości współczesnych katolickich szkół prawniczych}

Współcześnie większość katolickich szkół prawniczych praktycznie nie różni się od tych świeckich. Zwykle ich autodeklaracje o katolickiej tożsamości nie wykraczają poza "szereg dobrze dobranych sloganów" 29, gdy w rzeczywistości tożsamość ta to „niemal zapomniany historyczny $\operatorname{artefakt}^{\prime \prime 30}$. W ostatnim półwieczu problemy z kształtowaniem katolickiej tożsamości szkół prawniczych stały się głównie ideologicznej natury. Znaczna część zarządców, profesorów i studentów tych szkół podziela uproszczony, jednostronny i krytyczny obraz Kościoła katolickiego dominujący w liberalnej kulturze - jako instytucji „opresyjnej, zacofanej i patriarchalnej"31.

Zwraca uwage powierzchowne rozumienie tożsamości katolickich szkół prawniczych przez wielu ich wykładowców, w tym także osób duchownych. Zwykle posiada ona wymiar wyłącznie kulturowy, a nie intelektualny, pedagogiczny i formacyjny. Symbol krzyża czy portret św. Tomasza Morusa na ścianach sal wykładowych lub doroczna „czerwona msza" wpisują się w pewną ornamentykę, rodzaj "ceremonialnego deizmu"32. Nawet jednak ów kulturowy składnik katolickiej tożsamości podlega erozji. Przykładowo w okresie świąt Bożego Narodzenia w 2018 r. na stronie internetowej Georgetown Law School pojawiły się życzenia nie „Merry Christmas” a "Happy Holiday”. Zarządcy tej najbardziej prestiżowej katolickiej szkoły prawniczej i najwyżej klasyfikowanej w rankingu amerykańskich szkół prawniczych (14. pozycja na łącznie

28 Zob. A. Hendershott, Status Envy. The Politics of Catholic Higher Education, New Brunswick 2009, s. 90-91.

29 J.M. Breen, L.J. Strang, A Brief History..., s. 36.

${ }^{30}$ J.M. Breen, L.J. Strang, The Road..., s. 555.

31 J.M. Breen, L.J. Strang, A Brief History..., s. 37.

32 G. Maroń, Konstytucyjność aktów ceremonialnego deizmu w świetle orzecznictwa sądów USA, Przegląd Prawa Konstytucyjnego 2017, nr 3, s. 31-51. 
206 szkół prawniczych) ${ }^{33}$ tak bardzo chlubią się różnorodnością religijną i światopoglądową swoich studentów i profesorów, że jednocześnie wstydzą się tajemnicy wcielenia Syna Bożego, o ile w ogóle w nią jeszcze wierzą (sic! $)^{34}$.

Liczni autorzy w kreślonych przez siebie - być może nawet w dobrej wierze -wyobrażeniach katolickiej szkoły prawniczej pomijają kryterium zgodności działalności naukowo-dydaktycznej z nauczaniem Kościoła, a nierzadko wymóg taki otwarcie odrzucają. Do nauczania tego autorzy podchodzą nie tylko w sposób selektywny, ale i relatywizują jego wymowę. Wskazywane źródła inspiracji dla katolickich szkół prawniczych są bardziej subiektywną projekcją katolickiego nauczania niż wierną interpretacją Pisma Świętego oraz Tradycji i Magisterium Kościoła. Liczona w setkach pozycji literatura przedmiotu na temat tego, w czym powinna przejawić się katolicka tożsamość szkoły prawniczej ${ }^{35}$ nie przekłada się na zatrzymanie, czy tym bardziej odwrócenie, tendencji sekularyzacyjnych, jakim od dekad podlega katolicka edukacja prawnicza w Stanach Zjednoczonych $^{36}$. Skali problemu nie powinna przesłaniać okoliczność, że także niekatolickie religijnie afiliowane szkoły prawnicze dotknął poważny kryzys tożsamości.

Na czele sprzeniewierzania się wymogom Ex Corde Ecclesiae stoją amerykańskie jezuickie uniwersytety i ich szkoły prawnicze. Proaborcyjny profesor Georgetown Law School, a zarazem jezuicki kapłan i kongresman, R. Drinan, zachwalając własną uczelnię stwierdził: „Posiadamy trzech pełnoetatowych wykładowców będących jezuitami. Odprawiamy mszę świętą w południe. Co moglibyśmy więcej zrobić, aby uczynić ją

33 Zob. Best Law Schools [online], serwis internetowy U.S. News \& World Report, https://www.usnews.com/best-graduate-schools/top-law-schools/law-rankings [dostęp: $28.02 .2020 \mathrm{r}$.$] .$

34 Szerzej zob. Catholic Identity Concerns at Georgetown University [online], https:// newmansociety.org/wp-content/uploads/Dossier-Catholic-Identity-Concerns-at-Georgetown-Updated-Jan-2017.pdf [dostęp: 28.02.2020 r.].

35 Zob. bibliografię opracowaną przez Katolicki Uniwersytet Ameryki, serwis internetowy The Catholic University of America, https://www.law.edu/library/reference/ Catholic-Legal-Bibliography.cfm [dostęp: 31.12.2018 r.].

36 Zob. M.J. Perry, The Idea of a Catholic University, Marquette Law Review 1995, t. 78, nr 2; B. Bader Aldave, The Reality of a Catholic Law School, Marquette Law Review 1995, t. 78, nr 2; D.J. Morrissey, The Catholic Moment in Legal Education, Marquette Law Review 1995, t. 78, nr 2; J.M. Breen, Action as the Fruit of Contemplation: A Reply to Bryce, Donnelly, Kalscheur, and Nussbaum, Gonzaga Law Review 2007/2008, t. 43, nr 3, s. 645-669. 
katolicką?" ${ }^{37}$. Wtóruje mu profesor innej jezuickiej szkoły prawniczej Marquette University Law School S. Barkan, przekonując, że jezuicki model katolickiej edukacji prawniczej

nie musi oznaczać, że studenci są uczeni typowo katolickiego podejścia wobec prawa, że wykładowcy uprawiają naukę prawa z perspektywy katolickiej czy że studenci i wykładowcy są w większości katolikami. Niewielkie znaczenie powinno mieć umieszczanie krucyfiksów na ścianach sal zajęć, sprawowanie liturgii na terenie szkoły prawniczej czy obecność księży jako wykładowców ${ }^{38}$.

Często jezuickie szkoły prawnicze powołują się na lakoniczną , ,jezuicką tradycję" czy ",jezuickie dziedzictwo”, co jednak jest niczym więcej niż façon-de-parler ${ }^{39}$.

Bardzo popularne wśród zarządców i wykładowców katolickich szkół prawniczych jest przekonanie, że o katolickości tych uczelni świadczy uwzględnienie w programie nauczania problematyki sprawiedliwości społecznej, prowadzenie studenckich poradni świadczących darmową pomoc prawną osobom ubogim (legal clinics) lub aranżowanie różnych programów charytatywnych z udziałem studentów jako wolontariuszy. Każdy z tych trzech elementów, jakkolwiek zasługujący w pełni na uznanie, nie ma charakteru dystynktywnego dla katolickiej uczelni prawniczej, występując w działalności - i często na o wiele większą skalę - także świeckich szkół prawniczych ${ }^{40}$. Poszczególne cechy zaświadczające o katolickiej naturze szkoły prawniczej niekoniecznie muszą mieć charakter oryginalny czy wyłączny, ale nie sposób budować własnej tożsamości i odrębności jedynie w oparciu o przymioty uniwersalne. Angażowanie się studentów w bezinteresowną pomoc ludziom ubogim i w służbę społeczności lokalnej pod instytucjonalnym kierownictwem katolickiej szkoły prawniczej nie przestaje być formą implementacji katolickiej moralności tylko dlatego, że

37 D. Crumm i in., Can Catholic Colleges Pass Vatican's Test? New Ave Maria Law School Has Sparked Debate [online], serwis internetowy Detroit Free Press z dnia 12 maja 1999 r., s. 13.

38 S.M. Barkan, Jesuit Legal Education: Focusing the Vision, Marquette Law Review 1990, t. 74, nr 1, s. 107-108.

39 Zob. J.M. Breen, Justice and Jesuit Legal Education: A Critique, Loyola University Chicago Law Journal 2005, t. 36, s. 383-431.

40 Zob. M. Morey, J.J. Piderit, Catholic Higher Education. A Culture in Crisis, New York 2006, s. 57. 
aktywność wolontariacką podejmują także chrześcijanie innych wyznań, niechrześcijanie czy niewierzący. Z drugiej jednak strony tytułowanie się mianem katolickiej szkoły prawniczej wymaga świadomości tego, co ją wyróżnia i decyduje o jej jakości na tle innych szkół prawniczych.

Akcentowaniu roli sprawiedliwości społecznej w funkcjonowaniu katolickiej szkoły prawniczej często towarzyszy ambiwalentność odnośnie do rozumienia tego pojęcia. Deklarowane oddanie ideałowi sprawiedliwości społecznej - jako rzekomo przejaw katolickiej tożsamości - idzie często $\mathrm{w}$ parze $\mathrm{z}$ jawnym kontestowaniem oficjalnego nauczania katolickiego w przedmiocie np. rodziny czy moralności seksualnej ${ }^{41}$.

Innym niemal uniwersalnie zakładanym wyznacznikiem katolickości szkół prawniczych jest kulturowa różnorodność studentów i wykładowców oraz amorficzna „wspólnota” akademicka. Kościół katolicki rzeczywiście ma charakter powszechny (gr. Katholikos - powszechny) i inkluzywny, głosząc orędzie Chrystusa ludziom różnych ras i narodowości. Kościół uznaje też wolność religijną, przejawiając szacunek dla innych chrześcijan, wyznawców innych religii oraz agnostyków i ateistów ${ }^{42}$. Problem leży jednak w tym, że w promowaniu kulturowej różnorodności przez wiele katolickich szkół prawniczych nie chodzi o afirmowanie przyrodzonej godności każdej istoty ludzkiej i praw w niej umocowanych, ale o zrównanie wszystkich przekonań i sposobów życia. W imię szacunku dla kulturowej różnorodności studentów i profesorów akceptuje się np. działalność studenckich organizacji promujących aborcję czy aktywność wykładowców popierających małżeństwa jednopłciowe. Wyrozumiałość dla doznającego upadków grzesznika (co jak najbardziej katolickie) idzie $\mathrm{w}$ parze $\mathrm{z}$ apoteozą grzechu przedstawianego $\mathrm{w}$ kategoriach cnoty (co z katolicyzmem - czy szerzej chrześcijańskim miłosierdziem - nie ma już nic wspólnego).

Jeśliby przyjąć powyższe wątpliwe przesłanki katolickiej tożsamości szkół prawniczych, to okazałoby się, że niejedna świecka szkoła prawnicza jest bardziej katolicka od tej nominalnie katolickiej ${ }^{43}$.

${ }^{41}$ Zob. Ch. Wolfe, The Ideal of a (Catholic) Law School, Marquette Law Review 1995, t. 78 , nr 2, s. 495 .

${ }^{42}$ Zob. Deklaracja o wolności religijnej Dignitatis humanae z dnia 9 grudnia 1965 r. [online], http:/ / ptm.rel.pl/czytelnia/dokumenty/dokumenty-soborowe/sobor-watykanski-ii/168-deklaracja-o-wolnosci-religijnej-dignitatis-humanae.html [dostęp: 24.03 .2020 r.].

43 Zob. T.M. Mengler, Why Should a Catholic Law School be Catholic?, Journal of Catholic Social Thought 2010, t. 7, nr 2, s. 211-229, https://www.pdcnet.org/jcathsoc/content/jcat 
Z powyższych rozważań wyłania się dość pesymistyczny obraz współczesnej kondycji katolickich szkół prawniczych, jeśli kondycję tę mierzyć przez pryzmat katolickiej tożsamości omawianych szkół. Niniejszy obraz jest rezultatem pewnej generalizacji, a każde uogólnienie nigdy nie oddaje rzeczywistej postaci wszystkich elementów nim objętych. W historii amerykańskiej edukacji prawniczej liczonej od lat 70. ubiegłego wieku nie brakuje osób, inicjatyw i wydarzeń zaangażowanych czy wpisujących się w autentyczną misję katolickich szkół prawniczych.

Jakkolwiek konstytucja apostolska Ex Corde Ecclesiae spotkała się generalnie ze sceptycznym przyjęciem w katolickim prawniczym środowisku akademickim, to zarazem zainspirowała tych będących w mniejszości katolickich jurystów, którzy nigdy konformistycznie nie pogodzili się z postępującym rugowaniem katolickiej tożsamości szkół prawniczych. Od lat 90. coraz bardziej słyszalne, choć wciąż raczej odosobnione, są głosy o potrzebie poważnego traktowania przez katolickie szkoły prawnicze swojej religijnej afiliacji.

W 1999 r. utworzono Ave Maria School of Law, a dwa lata później University of St. Thomas School of Law. Zamierzeniem stojącym u podstaw powołania do życia dwóch nowych katolickich ośrodków edukacji prawniczej było nadanie tej edukacji prawdziwie katolickiego profilu. Zwłaszcza pierwsza z wymienionych szkół pozostaje wierna obranej misji ${ }^{44}$.

Pewnym pozytywnym ewenementem wśród katolickich szkół prawniczych jest deklaracja Ave Maria School of Law co do głównych założeń i celów swojej działalności (mission statement). Powinna ona stać się wzorcowa dla pozostałych formalnie katolickich szkół prawniczych. W deklaracji tej przeczytać można m.in.:

Ave Maria School of Law jest katolicką szkołą prawniczą zajmującą się kształceniem prawników o najwyższych umiejętnościach zawodowych. Inspirowana encykliką papieża Jana Pawła II Fides et Ratio, Ave Maria School of Law oferuje wyróżniającą się edukację prawniczą - edukację charakteryzującą się harmonią wiary i rozumu [oraz - G.M.] wiernością katolickiej wierze wyrażonej w Świętej Tradycji, Piśmie Świętym i nauczaniu władzy kościelnej.

hsoc_2010_0007_0002_0211_0229 [dostęp: 28.02.2020 r.].

44 Zob. M. Stetz, Best Law Schools for the Devout, PreLaw 2014, Winter, s. 30. Zob. też Ave Maria School of Law - School of Law, serwis internetowy The Princeton Review, https:/ / www.princetonreview.com/law/ave-maria-school-law-school-law-1037874 [dostęp: 28.02.2020 r.]. 
[Szkoła] potwierdza kładziony w katolickiej tradycji edukacji prawniczej nacisk na jedyną pewną podstawę ludzkiej wolności - prawo naturalne zapisane w sercu każdego człowieka. Potwierdzamy potrzebę, aby społeczeństwo na nowo odkryło te ludzkie i moralne prawdy, które wypływają z natury osoby ludzkiej i stanowią gwarancję wolności człowieka. Ave Maria School of Law uznaje centralną i nieodzowną rolę ordynariusza diecezji Venice w promowaniu, wspieraniu zachowania oraz wzmacnianiu katolickiej tożsamości szkoły. [Szkoła deklaruje, że proces dydaktyczny] wykracza poza szkolenie studentów w zakresie niezbędnych technicznych umiejętności prawniczych. Nasi studenci są kształceni do krytycznej refleksji nad prawem i jego rolą w systemie prawnym. Nasze nauczanie integruje moralne i społeczne nauczanie Kościoła katolickiego z bardziej konwencjonalnymi aspektami edukacji prawniczej i formuje osoby zdolne do prowadzenia kwitnącego życia w swoim prawniczym powołaniu [w] służbie dobru wspólnemu [i w poszanowaniu] godności osoby ludzkiej. [Działalność naukowa szkoły jest ukierunkowana na] badanie, odkrywanie i komunikowanie prawdy. [Wykładowcy uczelni] oceniają przedmiot swoich badań w świetle moralnego i społecznego nauczania Kościoła. [W końcu] społeczność wykładowców, zarządców, mentorów, studentów, absolwentów i pracowników personelu opiera się na przyrodzonej godności każdego człowieka, wynikającej z naszego stworzenia na obraz i podobieństwo Boga i podniesionego na nowy poziom przez nasze odkupienie przez Jezusa Chrystusa. W uznaniu godności wszystkich, wspólnota ta przyjmuje ludzi wszelkich wyznań, którzy pragną otrzymać wykształcenie, które oferujemy i dołączyć do nas w naszym oddaniu się prawdzie ${ }^{45}$.

Ambitnym wyzwaniem naukowym zapoczątkowanym kilkanaście lat temu jest Katolicka Teoria Prawa (Catholic Legal Theory) ${ }^{46}$, będąca nowym nurtem $\mathrm{w}$ amerykańskiej jurysprudencji $\mathrm{w}$ fazie in statu nascendi ${ }^{47}$. Dla jednego z inicjatorów Katolickiej Teorii Prawa, M. Scaperlandy, stanowi ona

45 Ave Maria School of Law Mission [online], serwis internetowy Ave Maria School of Law, https://www.avemarialaw.edu/campus-life/catholic-law-schools/ [dostęp: 28.02.2020 r.].

46 Zob. S.J. Stabile, Catholic Legal Theory, Journal of Catholic Legal Studies 2005, t. 44, s. 421-431; K.P. Lee, The Foundations of Catholic Legal Theory. A Primer, w: Recovering Self-Evident Truths: Catholic Perspectives on American Law, red. M.A. Scaperlanda, T.S. Collett, Washington 2007, s. 15-36.

47 G. Maroń, Katolicka teoria prawa jako kierunek we wspótczesnej amerykańskiej jurysprudencji, Gubernaculum et Administratio 2019, nr 1, s. 63-88. 
rozwijający się projekt katolickich profesorów prawa, filozofów prawa i innych, którzy w oparciu o katolicką intelektualną tradycję uczestniczą w budowaniu kultury, która docenia godność osoby ludzkiej, postrzega wspólnotę jako niezbędną dla rozwoju człowieka oraz poszukuje prawdziwej wolności dla osoby we wspólnocie ${ }^{48}$.

Od 2006 r. środowisko katolickich jurystów skupionych wokół tego projektu organizuje coroczne konferencje naukowe dotyczące katolickiej myśli prawniczej (The Conference on Catholic Legal Thought). W 2015 r. na Villanova University School of Law odbyła się konferencja naukowa (Catholic Legal Theory: Aspirations, Challenges, and Hopes), w trakcie której podjęto refleksję nad dotychczasowym dorobkiem i przyszłością Katolickiej Teorii Prawa ${ }^{49}$. Osoby zaangażowane w niniejszą inicjatywę prowadzą też prężnie działający blog internetowy The Mirror of Justice poświęcony "rozwijaniu Katolickiej Teorii Prawa”"50.

\section{Misja katolickich szkół prawniczych}

Istnienie katolickich szkół prawniczych jest celowe jedynie przy zachowaniu przez nie "poczucia własnej misji” ${ }^{51}$. Ich katolicka tożsamość powinna być kształtowana z uwzględnieniem zasad wyrażonych w Ex Corde Ecclesiae ${ }^{52}$. Na tożsamość tę składa się wielość elementów. Nie istnieje jeden „magiczny czynnik”, który per se decydowałby o statusie szkoły prawniczej jako szkoły katolickiej ${ }^{53}$.

48 M.A. Scaperlanda, Catholic Legal Theory [online], https://www.ewtn.com/catholicism/library/catholic-legal-theory-914 [dostęp: 24.03.2020 r.].

49 The Ninth Annual John F. Scarpa Conference on Law, Politics, and Culture [online], serwis internetowy Villanova University Charles Widger School of Law, https:/ / www1.villanova.edu/villanova/law/newsroom/webstories/2015/0325.html [dostęp: 28.02.2020 r.].

50 Serwis internetowy: Mirror of Justice, https://mirrorofjustice.blogs.com/ [dostęp: 28.02.2020 r.].

51 L.J. Nelson III, God and Man..., s. 144.

52 Podobnie zob. N.P. Cafardi, Catholic Law Schools and "Ex Corde Ecclesia”, or What Makes a Law School Catholic?, University of Toledo Law Review 2001, t. 33, s. 7-17; D.L. Gregory, Ch.J. Russo, Proposals to Counter Continuing Resistance to the Implementation of "Ex Corde Ecclesiae", St. John's Law Review 2000, t. 74, nr 3, s. 629-654.

53 Zob. F. Dutile, A Catholic Law University, Maybe; But a Catholic Law School?, w: The Challenge and Promise of a Catholic University, red. T. Hesburgh, Notre Dame 1994, s. 73. 
Osoby podejmujące wysiłki na rzecz wzmocnienia katolickiej tożsamości szkół prawniczych nie mogą zrażać się niezrozumieniem, a nawet potępieniem, ze strony części katolickiego środowiska akademickiego. Przykładowo jezuicki profesor teologii R. McBrien, inicjatywę utworzenia Ave Maria School of Law określił krytycznie jako „próbę sprowadzenia katolików do getta, pokazującą wielką naiwność co do tego o co naprawdę chodzi w katolickich szkołach prawniczych"54.

W pierwszej kolejności katolickość szkoły prawniczej musi przejawiać się w deklarowanym i realizowanym programie nauczania oraz działalności naukowej wykładowców ${ }^{55}$. Krytyka tego postulatu wśród części katolickich jurystów bierze się z mylnego jego pojmowania. Przykładowo J. Noonan trafnie zauważa, że akty normatywne czy orzeczenia sądowe mają określony tekst, który się nie zmienia w zależności od wyznania osoby czytającej go. Nie przekonuje jednak wyprowadzona z tego faktu konkluzja J. Noonana, że „powszechny charakter instytucji prawnych przemawia przeciwko jakiemukolwiek specyficznemu religijnemu zabarwieniu programu nauczania" ${ }^{56}$. W prawniczej edukacji prowadzonej z katolickiej perspektywy nie chodzi naiwnie o zastępowanie prawa - jako przedmiotu nauczania i badań - normami religijnymi czy katolicką doktryną, ale o uwzględnieniu tych drugich w refleksji nad systemem i porządkiem prawnym. Poszczególne dyscypliny nauk prawnych w różnym stopniu umożliwiają też czerpanie $\mathrm{z}$ katolickiego nauczania. Inny potencjał jest udziałem tego nauczania w odniesieniu do np. dogmatyki prawa rodzinnego, a inny w stosunku do prawa geologicznego i górniczego. Kościół katolicki nie wypowiada się na wszystkie kwestie prawnie relewantne. Nadużyciem byłoby omawianie partykularnego zagadnienia prawnego $\mathrm{z}$ użyciem religijnej narracji w sytuacji, gdy narracja ta nic nie wnosiłaby do rozumienia tego zagadnienia, będąc swoistą sztuką dla sztuki.

Obszarem prawoznawstwa poddawanym działalności naukowo-dydaktycznej, w którym katolicka tradycja intelektualna ma wiele do zaoferowania, są ogólne nauki prawne. Bardzo ważne, ale niewystarczające, jest upowszechnianie katolickiej teorii prawa naturalnego w ramach przedmiotu czy kursu Jurysprudencja. Ponadto katolicka teoria prawa

54 D. Crumm i in., Can Catholic Colleges...

55 Podobnie zob. J.M. Breen, The Air in the Balloon: Further Notes on Catholic and Jesuit Identity in Legal Education, Gonzaga Law Review 2007, t. 43, nr 1, s. 57.

56 J. Noonan, A Catholic Law School, Notre Dame Law Review 1992, t. 67, s. 1037. 
naturalnego nie musi być uprawiana jedynie w ujęciu neoscholastycznym, np. prezentowanym przez R. McInerny'ego i R. Hittingera. Twórczość J. Finnisa, G. Grisetza czy R.P. George'a pokazuje, że także tzw. nowa teoria prawa naturalnego może być wykorzystywana do obrony nauczania katolickiego w dziedzinie moralności.

Koncepcja jusnaturalizmu nie wyczerpuje katolicko sprofilowanej teorii i filozofii prawa. Nauczanie katolickie może stanowić punkt odniesienia $\mathrm{w}$ poznawaniu takich fundamentalnych nie tylko $\mathrm{w}$ prawoznawstwie pojęć, jak np. sprawiedliwość, słuszność, osoba, wina. Studenci katolickiej szkoły prawniczej powinni mieć możliwość zaznajomienia się nie tylko z dominującymi paradygmatami liberalizmu politycznego na czele z doktryną ekskluzywizmu i tezą prywatyzacji religii, ale i alternatywą wobec myśli liberalnej. Atrakcyjny dla studentów tego typu szkół wydaje się być rozwijany $\mathrm{w}$ ramach etyki prawniczej model uprawiania profesji prawniczej przez osobę wierzącą $w$ kategoriach wypełniania Bożego powołania w służbie bliźnim (tzw. religious lawyering). Pomocą dla przyszłych prawników w zachowaniu integralności religijnej w obliczu konfliktu sumienia z powinnościami zawodowymi jest wiedza o katolickiej doktrynie o współdziałaniu w grzechu. Obszarem dydaktycznej i naukowej eksploracji wartym podjęcia $\mathrm{w}$ katolickiej szkole prawniczej jest też instytucja klauzuli sumienia ${ }^{57}$.

Nie mniej podatnym na akomodację religijnej perspektywy obszarem prawoznawstwa są historyczne nauki prawne. Jakkolwiek doktryna i nauczanie katolickie nie naznaczyły postaci prawa amerykańskiego, o tyle chrześcijaństwo in generale - już w sposób niewątpliwy ${ }^{58}$.

Program nauczania katolickich szkół prawniczych wzbogaciłyby przedmioty, w ramach których kwestie jurydyczne omawiano by z perspektywy zarazem katolickiej, jak i interdyscyplinarnej, sięgając do dorobku np. katolickiej filozofii, teologii, nauki społecznej, kanonistyki czy historii kościoła katolickiego. Interdyscyplinarność jest coraz bardziej popularna w amerykańskiej jurysprudencji i edukacji prawniczej. Obiekcje budzi stan rzeczy, w którym student katolickiej szkoły prawniczej ma w ofercie edukacyjnej zajęcia np. Prawo i literatura czy Gender studies,

57 Zob. G. Maroń, Integralność religijna sędziego oraz argumentacja religijna w amerykańskim procesie orzeczniczym, Rzeszów 2018, passim.

58 Zob. H. Wayne House, The Christian and American Law: Christianity's Impact on America's Founding Documents and Future Direction, Grand Rapids 1998. 
ale już nie z prawa kanonicznego czy "prawowiernej” katolickiej nauki społecznej.

Konieczne jest przedstawianie studentom także zagadnień dogmatyczno-prawnych z uwzględnieniem doktryny katolickiej, zwłaszcza wówczas, gdy problematyka poszczególnych gałęzi prawa treściowo krzyżuje się z nauczaniem Kościoła katolickiego. Do dogmatyk szczególnie predysponowanych do akademickiego omówienia przez pryzmat doktryny katolickiej należą prawo rodzinne, prawo wyznaniowe, prawo karne, prawo konstytucyjne, prawo ubogich (poverty law), prawo pracy, prawo imigracyjne. Wraz z ewolucją nauczania Kościoła ujawnia ono swoją przydatność w analizowaniu kolejnych obszarów prawa, także tych dotychczas wydawałoby się nieposiadających z nią wyraźnych punktów stycznych, np. prawo ochrony środowiska ${ }^{59}$.

Postulat uwzględnienia nauczania katolickiego w działalności naukowo-dydaktycznej w odniesieniu do dogmatyk prawa nie ma - wbrew wątpliwościom niektórych - charakteru idealizacyjnego, lecz jest realizowalny. Świadczą o tym wydane w ostatnich dwóch dekadach monografie, w których przybliżono szereg kwestii dogmatyczno-prawnych z perspektywy katolickiej ${ }^{60}$.

Nauczanie prawa w optyce katolickiej nie oznacza i nie może oznaczać ignorowania postaci obowiązującego prawa. Przekazanie studentom katolickiej uczelni wiedzy o prawie takim jakim ono jest w świetle postanowień aktów normatywnych i orzecznictwa nie wyklucza jednak, a wręcz wymaga, poddania go krytycznej refleksji, ilekroć prawo to kłóci się z nauczaniem katolickim. Absolwenci katolickiej szkoły prawniczej nie mogą być ignorantami, u których wiedzę o obowiązującym prawie zastępuje życzeniowe myślenie, w którym zaciera się różnica pomiędzy de lege lata a de lege ferenda. Z drugiej jednak strony, w katolickiej uczelni nie wolno poprzestawać na sprawozdawczym zrelacjonowaniu postaci przepisów prawnych i sądowych precedensów. Można i należy oczekiwać, że wykładowcy nie tylko sygnalizacyjnie zwrócą słuchaczom uwagę na niespójność niektórych z tych przepisów i wyroków z doktryną katolicką, ale podejmą próbę wyjaśnienia studentom, w czym tkwi problematyczność

59 Zob. L.A. Silecchia, Laudato Si' and Care for Our Common Home: What Does it Mean for the Legal Professional?, Seattle Journal of Environmental Law 2016, t. 6, s. 1-12.

60 American Law..., red. R.J. Rychlak; Recovering Self-Evident..., red. M.A. Scaperlanda, T.S. Collett; B. Piatt, Catholic Legal Perspectives, Durham 2012. 
partykularnych postanowień prawa ${ }^{61}$. To z kolei może wymagać odwołania się w szczególności do katolickiej moralności, filozofii czy antropologii. Nie chodzi o to, aby poszczególne rozwiązania prawne przedstawiać jako złe - bo opozycyjne wobec oficjalnego nauczania Kościoła, ale złe - gdyż zaprzeczające obiektywnej prawdzie o człowieku i jego naturze - prawdzie, którą Kościół w swoim nauczaniu artykułuje i broni. Katolicka szkoła prawnicza musi być poddana "intelektualnemu poszukiwaniu prawdy", co z kolei wymaga założenia, że „istnieje prawda, a nie tylko idee, perspektywy i argumenty" 62 .

Niedouczonym byłby student kończący amerykańską katolicką szkołę prawniczą, w którego edukacji pominięto by odniesienie się do prawa kobiety ciężarnej do aborcji czy prawnej definicji małżeństwa jako związku dwóch osób jakiejkolwiek płci. Wątpliwa jest jednak katolicka tożsamość szkoły prawniczej, w której jedynie bezkrytycznie informuje się studentów o obowiązującym prawie w przedmiocie aborcji czy małżeństwa. Katolicka tożsamość szkoły prawniczej jest tym bardziej niewiarygodna, ilekroć precedensy Sądu Najwyższego legalizujące aborcję (Roe v. Wade $)^{63}$ czy redefiniujące małżeństwo (Obergefell v. Hodges) ${ }^{64}$ przedstawia się w sposób aprobatywny i apologetyczny. O wręcz zgorszeniu można natomiast mówić wtedy, gdy w katolickiej szkole prawniczej powszechne prawo do aborcji ukazuje się jako przejaw sprawiedliwości społecznej. Powołaniem katolickiej uczelni jest

odkrywanie korzeni i przyczyn najważniejszych problemów naszych czasów, zwracając szczególną uwagę na ich aspekty etyczny i religijny. Jeśli zaistnieje taka potrzeba, uniwersytet katolicki winien mieć odwagę głoszenia prawd niewygodnych, które nie schlebiają opinii publicznej, lecz są niezbędne ze względu na potrzebę obrony autentycznego dobra społeczeństwa ${ }^{65}$.

61 Podobnie zob. A.A. Leopold, M.E. Kaiser, The Lord in the Law: Reflections on a Catholic Law School, St. Mary's Law Journal 1993, t. 25, s. 399.

62 T. Mengler, Why Should..., s. 6.

63 Wyrok Sądu Najwyższego Stanów Zjednoczonych z dnia 22 stycznia 1973 r. w sprawie Roe v. Wade, 410 U.S. 113 (1973) [online], https:/ /cdn.loc.gov/service/ll/usrep/ usrep410/usrep410113/usrep410113.pdf [dostęp: 24.03.2020 r.].

64 Wyrok Sądu Najwyższego Stanów Zjednoczonych z dnia 26 czerwca 2015 r. w sprawie Obergefell v. Hodges, 576 U.S. (2015) [online], https://www.supremecourt.gov/ opinions/14pdf/14-556_3204.pdf [dostęp: 24.03.2020 r.].

65 Pkt 32 ECE. 
Studenci prawa powinni zostać zaznajomieni z wielością formułowanych $w$ jurysprudencji i orzecznictwie stanowisk na dane zagadnienie prawne, nawet tych ewidentnie opozycyjnych wobec nauczania katolickiego. Od wykładowców katolickiej uczelni można jednak oczekiwać ponadto uświadomienia i uwrażliwienia studentów na to, że poszczególne regulacje normatywne, rozstrzygnięcia sądowe czy nawet bardzo popularne poglądy jurysprudencji przeczą godności życia ludzkiego i nie sprzyjają sprawiedliwości społecznej ${ }^{66}$.

Powyższe uwagi zachowują aktualność także w odniesieniu do działalności naukowej pracowników katolickiej szkoły prawniczej. „W pracach badawczych i w nauczaniu wszyscy katoliccy pracownicy naukowi winni wiernie przyjmować, a wszyscy pozostali respektować, katolicką doktrynę i moralność" (art. 4.3 ECE).

Konieczność uprawiania dydaktyki i nauki prawa z perspektywy katolickiej nie neguje właściwie rozumianej wolności akademickiej ${ }^{67}$. Granicę tej wolności wyznaczają bowiem „wymogi prawdy i dobra wspólnego" (pkt 29 i art. 2.5 ECE). „Poszukiwanie prawdy poprzez badania naukowe” oraz „przechowywanie i przekazywanie wiedzy dla dobra społeczeństwa" stanowi podstawową misję katolickiej uczelni (pkt $30 \mathrm{ECE})^{68}$. Wymóg „wiernego przyjmowania” doktryny katolickiej w działalności naukowo-dydaktycznej nie jest ubezwłasnowolnieniem naukowca, uczynieniem z niego bezrefleksyjnego apologety tej doktryny. Profesor prawa także na katolickiej uczelni musi „działać w sposób ściśle naukowy i krytyczny" (pkt 12 ECE). Bycie wierzącym nie neguje statusu naukowca, skoro - jak zauważa papież Benedykt XVI w przemówieniu do katolickich wykładowców - "ten kto poszukuje prawdy, żyje wiarą" ${ }^{69}$.

Kluczowy dla tożsamości katolickiej szkoły prawniczej jest dobór odpowiedniej kadry, w postaci osób "gotowych i zdolnych umacniać" tę

66 Zob. J. Fitzgerald, Today's Catholic Law Schools in Theory and Practice: Are We Preserving Our Identity, Notre Dame Journal of Law, Ethics \& Public Policy 2001, t. 15, s. 278.

67 Odmiennie zob. D. Gordon, "Ex Corde Ecclesiae”: The Conflict Created for American Catholic Law Schools, Gonzaga Law Review 1999, t. 34, s. 125-156.

68 Zob. V.V. Miles, Faith-Based Law Schools: Making Mission Matter, Catholic University Law Review 2017, t. 66, nr 4, s. 795-821.

69 Przemówienie papieża Benedykta XVI do katolickich wykładowców, Katolicki Uniwersytet Ameryki w Waszyngtonie (Waszyngton, 17 kwietnia 2008 r.), http:// w2.vatican.va/content/benedict-xvi/en/speeches/2008/april/documents/hf_ben-xvi_ spe_20080417_cath-univ-washington.html [dostęp: 24.03 .2020 r.]. 
tożsamość" (art. 4.1 ECE). Można angażować wykładowców o innym wyznaniu czy bezwyznaniowych, ale pod warunkiem co najmniej „uznawania i respektowania” przez nich „katolickiego charakteru” i „,tożsamości” zatrudniającej ich uczelni (art. 4.2 i 4.4 ECE). Celem uniknięcia nieporozumień i rozbieżności oczekiwań pomiędzy katolicką szkołą prawniczą a wykładowcami należy $\mathrm{w}$ momencie mianowania poinformować ich o katolickiej tożsamości szkoły i jej implikacjach (art. 4.2 ECE). Krytycznie należy odnieść się do polityki zatrudniania wykładowców, katolików lub niekatolików, którzy w swojej dotychczasowej działalności naukowej lub publicznych wypowiedziach opowiadali się za prawną afirmacją „działań ze swej istoty złych czy wysoce niemoralnych"70.

Wydaje się, iż conditio sine qua non pielęgnowania katolickiej tożsamości uczelni jest to, aby większość kadry stanowili katolicy. Założenie, że „szkoła prawnicza może być katolicka bez katolików jest absurdalne"71. Bezcelowe jest „udawanie, że to jaką religię wyznają wykładowcy nie czyni żadnej różnicy"72.

Przynależność wykładowcy do kościoła katolickiego, a nawet podzielanie katolickiego nauczania oraz kierowanie się nim w życiu prywatnym nie wystarcza jednak do skutecznego inkorporowania katolickiej perspektywy do procesu naukowo-dydaktycznego ${ }^{73}$. Tożsamość katolickiej uczelni uzależniona jest w istotny sposób nie tylko od „wierności doktrynie katolickiej”, ale i od „poziomu wykładowców” (art. 4.1 ECE).

Dziekan St. Mary University School of Law John Hervey w 1961 r. wzywał wykładowców religijnie afiliowanych szkół prawniczych, aby „na nowo przestudiowali chrześcijańskie zasady i wówczas, w stopniu w jakim to możliwe, nauczali treści programowych, kładąc nacisk na te zasady"74. Podobnie G. Bradley przekonuje, że „katolicki wykładowca musi być wyczulony na znaczenie prawd wiary dla kwestii prawnych"75. Katolicki profesor nieświadomy doniosłości katolickiej tradycji

70 J.M. Breen, L.J. Strang, Brief History..., s. 39.

71 P. Schiltz, Does the World Really Need Another Catholic Law School [online], serwis internetowy University of St. Thomas, http:/ / www.stthomas.edu/lawschool/articles/Does the_worldreally.need.cfm [dostęp: 31.12.2018 r.].

72 J. Noonan, A Catholic..., s. 1044.

73 Zob. J.M. Breen, L.J. Strang, Brief History..., s. 39.

74 J.G. Hervey, Christian Precepts in the Common Law, The Catholic Lawyer 1961, t. 7, nr 4, s. 303.

75 G. Bradley, Catholic Faith and Legal Scholarship, Journal of Legal Education 1997, t. 47, s. 17. 
intelektualnej dla lepszego poznania prawa nie jest $\mathrm{w}$ stanie tak $\mathrm{w}$ działalności dydaktycznej jak i naukowej realizować misji reprezentowanej uczelni. Nemo dat qui non habet ${ }^{76}$.

Wymogi akredytacyjne ABA i AALS jakkolwiek nie sprzyjają poszanowaniu katolickiej tożsamości szkół prawniczych, to zarazem nieuprawnione jest twierdzenie, że wymogi te kategorycznie stoją na przeszkodzie implementacji norm Ex Corde Ecclesiae $e^{77}$. Przepisy AALS zakazują szkołom prawniczym dyskryminacji wobec pracowników, aplikantów na studia i studentów ze względu na rasę, kolor, religię, narodowość, płeć, gender, orientację seksualną, wiek czy niepełnosprawność. Zarazem umożliwiają szkołom o religijnej afiliacji czy religijnych celach przyjęcie preferencyjnych praktyk zatrudniania oraz naboru studentów, bezpośrednio powiązanych z tą afiliacją i celami pod warunkiem, że m.in. praktyki te zostaną uprzednio podane do wiadomości, nie wpłyną negatywnie na poziom edukacji prawniczej (np. poprzez „brak dostatecznej intelektualnej różnorodności"), nie mają charakteru dyskryminacyjnego oraz nie polegają na odgórnym wyłączeniu lub na wprowadzeniu limitu liczbowego osób ze względu na ich religię ${ }^{78}$. Podobne regulacje przyjęła ABA, zastrzegając ponadto, że polityka naboru studentów czy zatrudniania pracowników przez uczelnię o religijnej afiliacji i celu nie może naruszać wolności akademickiej oraz musi być zgodna z 1. poprawką do Konstytucji Stanów Zjednoczonych. Jednocześnie przepis ABA stanowi, że „ograniczenia wolności akademickiej z powodu religijnych czy innych celów instytucji [edukacyjnej] powinny być wyraźnie wyrażone na piśmie w chwili nominacji [pracownika]"79.

76 Zob. J.M. Breen, The Air in the Balloon..., s. 70.

77 Zob. A.L. Anderson, "Ex Corde Ecclesiae”: Obstacle or Opportunity for Catholic Affiliated Law Schools, Gonzaga Law Review 1999, t. 34, s. 121.

78 Executive Committee Regulations of the Association of American Law Schools, Section 6.3.1 [online], https://www.aals.org/about/handbook/executive-committee-regulations/ [dostęp: 24.03.2020 r.] oraz Bylaws of the Association of American Law Schools, Section 6.3 [online], https://www.aals.org/about/handbook/bylaws/ [dostęp: 24.03.2020 r.].

79 ABA Standards and Rules of Procedure for Approval of Law Schools 2019-2020, Standard 205c oraz Appendix 1: Statement on Academic Freedom and Tenure: Academic Freedom 2 [online], https://www.americanbar.org/groups/legal_education/resources/ standards/ [dostęp: 24.03.2020 r.]. 
Katolicka szkoła prawnicza nie powinna nagradzać czy honorować osób, których publicznie głoszone poglądy i działania pozostają w głębokiej sprzeczności z doktryną katolicką ${ }^{80}$. Sceptycznie należy też odnieść się do zapraszania ich jako prelegentów okolicznościowych wykładów.

Podobnie jak nagradzanie osób propagujących poglądy będące $\mathrm{w}$ radykalnej opozycji do nauczania katolickiego może stanowić źródło konfuzji i zgorszenia wśród katolików, tak również oficjalne uznawanie i wspieranie przez władze katolickiej szkoły prawniczej studenckich organizacji promujących treści sprzeczne z doktryną katolicką podkopuje katolicką tożsamość tej szkoły. Jakkolwiek nierzadko amerykańskie sądy zmuszają religijnie afiliowane uczelnie do „uznawania” i równego traktowania studenckich organizacji prowadzących politykę niezgodną z daną doktryną religijną ${ }^{81}$ o tyle case law nie wymaga od władz uczelni aktywnego „popierania”, a tym bardziej „promowania” tych organizacji. Nie do zaakceptowania jest sytuacja, gdy decydenci katolickich szkół prawniczych oficjalnie czy nieoficjalnie udzielają swoistego imprimatur studenckim organizacjom, których misja sprowadza się np. do upowszechniania idei praw reprodukcyjnych rozumianych jako prawo do powszechnie dostępnej aborcji lub rozpropagowujących ideologię gender ${ }^{82}$.

Katolicka szkoła prawnicza broniąc swojej tożsamości zarazem nie może przyjmować postawy izolacjonistycznej i samoalienującej. Zadaniem katolików jest uczestniczyć w kulturze, aby ją zmieniać na lepsze, a nie wycofywać się z niej. Wierność ideałom katolicyzmu wymaga otwartości na dialog z osobami inaczej myślącymi. Akceptowalne jest partycypowanie profesorów prawa zajmujących stanowisko krytyczne wobec katolickiego nauczania w konferencjach naukowych organizowanych przez

80 Podobnie zob. United States Conferences of Catholic Bishops: Catholics in Political Life (2004), serwis internetowy United States Conferences of Catholic Bishops, http://www. usccb.org/issues-and-action/faithful-citizenship/church-teaching/catholics-in-political-life.cfm [dostęp: 24.03.2020 r.]; R.W. Garnett, Whom Should a Catholic University Honor?: „Speaking" with Integrity, Journal of Catholic Legal Studies 2010, t. 49, nr 2, s. 233-242.

81 Wyrok federalnego Sądu Apelacyjnego dla Dystryktu Kolumbii z dnia 20 listopada 1987 r. w sprawie Gay Rights Coalition v. Georgetown University [online], https:// law.justia.com/cases/district-of-columbia/court-of-appeals/1987/84-50-4.html [dostęp: 24.03.2020 r.].

82 Zob. A. Hendershott, Some Catholic Law Schools Train Abortion Advocates [online], serwis internetowy CRISIS Magazine, https://www.crisismagazine.com/2015/some-catholic-law-schools-train-abortion-advocates [dostęp: 28.02 .2020 r.]. 
katolicką szkołę prawniczą. Podobnie kadra katolickiej szkoły prawniczej może współpracować z nimi w działalności naukowo-wydawniczej. W przeciwnym wypadku środowisko katolickich jurystów stałoby się hermetycznym "towarzystwem wzajemnej adoracji”. Uprawianie nauki ze swej istoty zakłada polemiczną konwersację z osobami prezentującymi poglądy inne od naszych własnych.

Szacunek dla osób reprezentujących konkurencyjne poglądy i uczestniczenie $\mathrm{z}$ nimi $\mathrm{w}$ naukowym dyskursie na partnerskich zasadach nie może jednak hołdować postmodernistycznemu paradygmatowi o braku obiektywnej prawdy. W działalności naukowej i dydaktycznej wykładowcom katolickich szkół prawniczych nie wolno w imię źle pojmowanej tolerancji konformistycznie przyjmować, że wszystkie przekonania są jednakowo wartościowe ${ }^{83}$. $Z$ wymogu poszukiwania obiektywnej prawdy nie można zrezygnować na rzecz „kryterium szczerości, autentyczności, «zgody z samym sobą»”, gdyż wizja, w której „każdy człowiek staje wobec własnej prawdy, różnej od prawdy innych” prowadzi do „zaprzeczenia samej idei natury ludzkiej" ${ }^{84}$.

Zgodnie z Ex Corde Ecclesiae katolicka szkoła prawnicza powinna współdziałać z właściwym miejscowo biskupem. Relacje zarządców szkoły z ordynariuszem ma charakteryzować „wzajemne zaufanie, konsekwentna współpraca i nieustanny dialog" (pkt 28 ECE). Obecnie wiele katolickich szkół prawniczych w Stanach Zjednoczonych znamionuje w tym względzie głęboki separatyzm i absolutystyczne rozumienie autonomii. Tymczasem „kontakty osobiste i duszpasterskie” władzy kościelnej ze szkołą prawniczą służą „zachowaniu i umacnianiu” katolickiej tożsamości tej szkoły, nie będąc ukierunkowane na odgórne zarządzanie czy rygorystyczne cenzurowanie działalności naukowo-dydaktycznej.

Katolicka szkoła prawnicza nie może ponadto zaniedbywać opieki pastoralnej dla swoich studentów i pracowników, zapewniając im odpowiednie warunki nie tylko do rozwoju intelektualnego, ale także tego duchowego. Na terenie campusu powinna znajdować się kaplica, w której sprawowana jest codzienna eucharystia oraz funkcjonować akademickie

83 Zob. D. DeWolf, R. Araujo, And God's Justice Shall Become Ours: Reflections on Teaching Law in a Catholic University, Regent University Law Review 1999, t. 11, s. 47-48.

84 Jan Paweł II, Encyklika "Veritatis splendor". Do wszystkich biskupów Kościoła katolickiego o niektórych podstawowych problemach nauczania moralnego Kościoła (6 sierpnia 1993 r.), 32, http://www.vatican.va/content/john-paul-ii/pl/encyclicals/documents/hf_jp-ii_enc_ 06081993_veritatis-splendor.html [dostęp: 28.02.2020 r.]. 
duszpasterstwo. Zewnętrznym wyrazem przynależności do wspólnoty chrześcijańskiej jest obecność krzyża na ścianach pomieszczeń szkoły.

W końcu na katolicką tożsamość szkoły prawniczej składa się angażowanie jej pracowników i studentów w pomoc bliźnim. Świadectwem chrześcijańskiej miłości drugiego człowieka jest zwłaszcza prowadzenie klinik prawa oraz woluntarystyczne uczestnictwo studentów i wykładowców w różnych programach prac na rzecz społeczności lokalnej (community service).

\section{Zakończenie}

Kościół katolicki patronując szkole prawniczej nieupowszechniającej ani nawet nie przyznającej się do duchowo-intelektualnej spuścizny katolicyzmu staje się niewiarygodny nie tylko wobec siebie samego, ale także wobec "Tego, który jest jego głową". Ignorując katolicką intelektualną tradycję szkoły prawnicze "stają się hipokrytami”. Ich powołaniem jest przecież „promowanie własnych poglądów, przekonań i kultury bez względu na społeczną presję, aby czynić inaczej". Święty Paweł w Liście do Rzymian napisał: „Bo ja nie wstydzę się Ewangelii, jest bowiem ona mocą Bożą ku zbawieniu dla każdego wierzącego" ${ }^{85}$. Pora, aby katolickie szkoły prawnicze „poszły za tym przykładem i «głosiły Ewangelię wszelkiemu stworzeniu» ${ }^{86}, \mathrm{w}$ tym studentom prawa" ${ }^{87}$.

Diagnoza i postulat wyrażone w powyższym akapicie nie są autorstwa piszącego niniejszy artykuł - choć je podziela - ale będącego mormonem absolwenta jednej z jezuickich szkół prawniczych. Zasadność dalszego istnienia katolickich uniwersytetów, w tym także wydziałów prawa, zależy od ich gotowości i zdolności do realizowania misji, którą jest „nieustanne poszukiwanie prawdy poprzez badania naukowe" oraz "przechowywanie i przekazywanie wiedzy dla dobra społeczeństwa" (pkt 30 ECE). Katolicka szkoła prawnicza, nie tylko w Stanach Zjednoczonych, musi dążyć do integralności własnej religijnej tożsamości z pełnym profesjonalizmem, wiary

${ }^{85} \mathrm{Rz} 1,16$.

$86 \mathrm{Mk} 16,15$.

87 S.K. Nussbaum, No Man Can Serve Two Masters: A Student Perspective on Jesuit Legal Education, Gonzaga Law Review 2007/2008, t. 43, nr 3, s. 639-642. 
z rozumem, respektowania katolickiej doktryny i moralności z działaniem ściśle naukowym i krytycznym właściwym dla wolności akademickiej, przekazywania wiedzy i dbałości o rozwój intelektualny z formacją studentów i troską o religijny wymiar ich życia. Udawanie katolickiej tożsamości, czy traktowanie jej z laksyzmem, jest bezprzedmiotowe. Katolickie szkoły prawnicze nie mogą wstydzić się bycia katolickimi i przyjmować postawy mimezji wobec szkół świeckich. Rezygnacja z własnej tożsamości w imię przypodobania się prawniczemu i kulturowemu establishmentowi jest niegodne nie tylko chrześcijanina, ale i naukowca, który przecież prowadzi działalność naukowo-dydaktyczną nec ad vanam captandam gloriam, sed quo magis veritas propagetur et lux eius, qua salus humani generis continetur, clarius effulgeat. Zarządcy i wykładowcy katolickich szkół prawniczych niech będą pomni słów Jezusa Chrystusa: „Wy jesteście solą dla ziemi. Lecz jeśli sól utraci swój smak, czymże ją posolić? Na nic się już nie przyda, chyba na wyrzucenie i podeptanie przez ludzi" 88 .

Słowa kluczowe: katolicka szkoła prawnicza, katolicka tożsamość, Stany Zjednoczone, edukacja prawnicza

\section{Bibliografia}

Anderson A.L., Ex Corde Ecclesiae: Obstacle or Opportunity for Catholic Affiliated Law Schools, Gonzaga Law Review 1999, t. 34.

Bader Aldave B., The Reality of a Catholic Law School, Marquette Law Review 1995, t. 78, nr 2.

Barkan S.M., Jesuit Legal Education: Focusing the Vision, Marquette Law Review 1990, t. 74, nr 1.

Bradley G., Catholic Faith and Legal Scholarship, Journal of Legal Education 1997, t. 47. Breen J.M., L.J. Strang, A Brief History of American Catholic Legal Education: The Arc of an Uncertain Identity, w: American Law from a Catholic Perspective: Through a Clearer Lens, red. R.J. Rychlak, Lanham 2016.

Breen J.M., L.J. Strang, The Forgotten Jurisprudential Debate: Catholic Legal Thought's Response to Legal Realism, Marquette Law Review 2015, t. 98, nr 3. 
Breen J.M., L.J. Strang, The Thinness of Catholic Legal Education, a Review of Robert J. Kaczorowski, Fordham University Law School: A History, University of St. Thomas Law Journal 2019, t. 15, nr 2.

Breen J.M., L.J. Strang, The Road Not Taken: Catholic Legal Education at the Middle of the Twentieth Century, American Journal of Legal History 2011, t. 51, nr 4.

Breen J.M., L.J. Strang, The Golden Age that Never Was: Catholic Law Schools from 1930-1960 and the Question of Identity, Journal of Catholic Social Thought 2010, t. 7, nr 2 .

Breen J.M., Action as the Fruit of Contemplation: A Reply to Bryce, Donnelly, Kalscheur, and Nussbaum, Gonzaga Law Review 2007/2008, t. 43, nr 3.

Breen J.M., The Air in the Balloon: Further Notes on Catholic and Jesuit Identity in Legal Education, Gonzaga Law Review 2007, t. 43, nr 1.

Breen J.M., Justice and Jesuit Legal Education: A Critique, Loyola University Chicago Law Journal 2005, t. 36.

Cafardi N.P., Catholic Law Schools and "Ex Corde Ecclesiae”, or What Makes a Law School Catholic?, University of Toledo Law Review 2001, t. 33.

D'Agostino T.J., Religious Charter Schools: Are They Constitutionally Permissible?, Journal of School Choice 2018, t. 12, nr 4.

DeWolf D., R. Araujo, And God's Justice Shall Become Ours: Reflections on Teaching Law in a Catholic University, Regent University Law Review 1999, t. 11.

Dutile F., A Catholic Law University, Maybe; But a Catholic Law School?, w: The Challenge and Promise of a Catholic University, red. T. Hesburgh, Notre Dame 1994.

Fitzgerald J., Today's Catholic Law Schools in Theory and Practice: Are We Preserving Our Identity, Notre Dame Journal of Law, Ethics \& Public Policy 2001, t. 15.

Garnett R.W., Whom Should a Catholic University Honor?: "Speaking" with Integrity, Journal of Catholic Legal Studies 2010, t. 49, nr 2.

Gordon D., "Ex Corde Ecclesiae": The Conflict Created for American Catholic Law Schools, Gonzaga Law Review 1999, t. 34.

Gregory D.L., Ch.J. Russo, Proposals to Counter Continuing Resistance to the Implementation of "Ex Corde Ecclesiae", St. John's Law Review 2000, t. 74, nr 3.

Hendershott A., Status Envy. The Politics of Catholic Higher Education, New Brunswick 2009.

Hervey J.G., Christian Precepts in the Common Law, The Catholic Lawyer 1961, t. 7, nr 4.

Holmes O.W., Natural Law, Harvard Law Review 1918, t. 32.

Jenkins P., The New Anti-Catholicism: The Last Acceptable Prejudice, New York 2003.

Lee K.P., The Foundations of Catholic Legal Theory. A Primer, w: Recovering Self-Evident Truths: Catholic Perspectives on American Law, red. M.A. Scaperlanda, T.S. Collett, Washington 2007.

Leopold A.A., M.E. Kaiser, The Lord in the Law: Reflections on a Catholic Law School, St. Mary's Law Journal 1993, t. 25. 
MacIntyre A., God, Philosophy, Universities: A Selective History of the Catholic Philosophical Tradition, Lanham 2009.

Maron G., Integralność religijna sędziego oraz argumentacja religijna w amerykańskim procesie orzeczniczym, Rzeszów 2018.

Maroń G., Katolicka teoria prawa jako kierunek we współczesnej amerykańskiej jurysprudencji, Gubernaculum et Administratio 2019, nr 1.

Maroń G., Konstytucyjność aktów ceremonialnego deizmu w świetle orzecznictwa sądów USA, Przegląd Prawa Konstytucyjnego 2017, nr 3.

Marsden G.M., The Outrageous Idea of Christian Scholarship, New York 1998.

Mengler T.M., Why Should a Catholic Law School Be Catholic?, Journal of Catholic Social Thought 2010, t. 7, nr 2.

Miles V.V., Faith-Based Law Schools: Making Mission Matter, Catholic University Law Review 2017, t. 66, nr 4.

Morey M., J.J. Piderit, Catholic Higher Education. A Culture in Crisis, New York 2006.

Morrissey D.J., The Catholic Moment in Legal Education, Marquette Law Review 1995, t. 78, nr 2.

Nelson III L.J., God and Man in the Catholic Law School, The Catholic Lawyer 1981, t. 26 , nr 2 .

Noonan J., A Catholic Law School, Notre Dame Law Review 1992, t. 67.

Nussbaum S.K., No Man Can Serve Two Masters: A Student Perspective on Jesuit Legal Education, Gonzaga Law Review 2007/2008, t. 43, nr 3.

Owens D., American Law Schools in Their Second Century, Journal of Legal Education 1976 , t. 28, nr 2.

Perry M.J., The Idea of a Catholic University, Marquette Law Review 1995, t. 78, nr 2.

Piatt B., Catholic Legal Perspectives, Durham 2012.

Rochowicz A., Edukacja prawnicza w USA, Palestra 1994, nr 7/8.

Shaffer T., Christian Theories of Professional Responsibility, Southern California Law Review 1975, t. 48.

Silecchia L.A., Laudato Si' and Care for Our Common Home: What Does it Mean for the Legal Professional?, Seattle Journal of Environmental Law 2016, t. 6.

Stabile S.J., Catholic Legal Theory, Journal of Catholic Legal Studies 2005, t. 44.

Stetz M., Best Law Schools for the Devout, PreLaw 2014, Winter, s. 30.

Wayne House H., The Christian and American Law: Christianity's Impact on America's Founding Documents and Future Direction, Grand Rapids 1998.

Wolfe Ch., The Ideal of a (Catholic) Law School, Marquette Law Review 1995, t. 78, nr 2. 


\section{HISTORY, PRESENT AND FUTURE OF CATHOLIC LAW SCHOOLS - THE AMERICAN PERSPECTIVE}

\section{Sum mary}

The article presents the genesis, evolution and current status of Catholic law schools in the USA against the background of social and cultural changes. Since the 1960s and 1970s most of the nominally Catholic law schools in the United States have practically been no different from their secular counterparts. In the Author's opinion, the clear Catholic identity of those schools should be framed in the light of the provisions of Pope John Paul II's Apostolic Constitution Ex Corde Ecclesiae. In the first place, this identity should manifest itself in the research and teaching of a wide range of legal topics. The curriculum and the scholarship of the faculty should take into account the rich Catholic philosophical and theological tradition. Catholic law schools, not only those in the United States, are called to the integrity of their religious identity with full professionalism, faith with reason, respect for Catholic doctrine and morality with strictly scientific and critical methodology aimed at seeking and communicating objective truth, transferring knowledge to students with their spiritual- and intellectual formation.

Key words: Catholic law school, Catholic identity, United States, legal education

\section{ИСТОРИЯ, НАСТОЯЩЕЕ И БУДУЩЕЕ КАТОЛИЧЕСКИХ ЮРИДИЧЕСКИХ ШКОЛ - АМЕРИКАНСКАЯ ПЕРСПЕКТИВА}

\section{Резюме}

В статье представлены генезис, эволюция и современное состояние католических юридических школ в США на фоне происходящих социальных и культурных изменений. С 60-70-х годов прошлого века большинство католических юридических школ в Соединенных Штатах практически не отличались от своих светских эквивалентов. По мнению автора, четкая католическая идентичность этих школ должна определяться положениями Апостольской конституции Иоанна Павла II Ex Corde Ecclesiae. Во-первых, эта идентичность должна проявляться в исследовательской и преподавательской деятельности. Учебный план для студентов и научное творчество преподавателей должны учитывать богатую католическую философскую и теологическую традицию. Католические юридические школы, не только в Соединенных Штатах, предназначены для интеграции религиозной идентичности с полным профессионализмом, веры с разумом, уважения к католической доктрине и морали со строго научными и критическими 
действиями, направленными на поиск и распространение объективной истины, передачу знаний учащимся при их духовно-интеллектуальном формировании.

Ключевые слова: католическая юридическая школа, католическая идентичность, Соединенные Штаты, юридическое образование 